\title{
Validation and classification of RNA binding proteins identified by mRNA interactome capture
}

\author{
VAISHALI, ${ }^{1,2,6}$ LYUDMILA DIMITROVA-PATERNOGA, ${ }^{1,3,6} \mathrm{KEVIN} \mathrm{HAUBRICH}^{3,6} \mathrm{MAI}^{3} \mathrm{SUN}^{,}{ }^{4}$ ANNE EPHRUSSI, ${ }^{1}$ \\ and JANOSCH HENNIG ${ }^{3,5}$ \\ ${ }^{1}$ Developmental Biology Unit, EMBL Heidelberg, 69117 Heidelberg, Germany \\ ${ }^{2}$ Faculty of Biosciences, Heidelberg University, Heidelberg 69120, Germany \\ ${ }^{3}$ Structural and Computational Biology Unit, EMBL Heidelberg, 69117 Heidelberg, Germany \\ ${ }^{4}$ Genome Biology Unit, EMBL Heidelberg, 69117 Heidelberg, Germany \\ ${ }^{5}$ Biochemistry IV, Biophysical Chemistry, University of Bayreuth, 95447 Bayreuth, Germany
}

\begin{abstract}
RNA binding proteins (RBPs) take part in all steps of the RNA life cycle and are often essential for cell viability. Most RBPs have a modular organization and comprise a set of canonical RNA binding domains. However, in recent years a number of high-throughput mRNA interactome studies on yeast, mammalian cell lines, and whole organisms have uncovered a multitude of novel mRNA interacting proteins that lack classical RNA binding domains. Whereas a few have been confirmed to be direct and functionally relevant RNA binders, biochemical and functional validation of RNA binding of most others is lacking. In this study, we used a combination of NMR spectroscopy and biochemical studies to test the RNA binding properties of six putative RBPs. Half of the analyzed proteins showed no interaction, whereas the other half displayed weak chemical shift perturbations upon titration with RNA. One of the candidates we found to interact weakly with RNA in vitro is Drosophila melanogaster end binding protein 1 (EB1), a master regulator of microtubule plus-end dynamics. Further analysis showed that EB1's RNA binding occurs on the same surface as that with which EB1 interacts with microtubules. RNA immunoprecipitation and colocalization experiments suggest that EB1 is a rather nonspecific, opportunistic RNA binder. Our data suggest that care should be taken when embarking on an RNA binding study involving these unconventional, novel RBPs, and we recommend initial and simple in vitro RNA binding experiments.
\end{abstract}

Keywords: mRNA interactome; RNA binding proteins; EB1; TRIM proteins; Tropomyosin; Thioredoxin

\section{INTRODUCTION}

Ribonucleoprotein particles (RNPs) are RNA and protein assemblies that carry out or regulate essential functions in cells, including transcription, splicing, translation, and RNA decay among others (Cech and Steitz 2014). The proteins that bind RNA molecules directly-so-called RNA binding proteins (RBPs) - typically have a modular organization and comprise a set of globular RNA binding domains (RBDs). Among the most abundant RBDs are the RRM (RNA recognition motif) domains, which are present in roughly two thirds of all studied mRNA binding proteins (mRBPs), followed by DEAD-box helicase domains, zinc fingers, $\mathrm{KH}$ domains, and cold shock domains (CSDs)

\footnotetext{
${ }^{6}$ These authors contributed equally to this work.

Corresponding authors: anne.ephrussi@embl.org, janosch. hennig@embl.de

Article is online at http://www.rnajournal.org/cgi/doi/10.1261/rna. 078700.121. Freely available online through the RNA Open Access option.
}

(Lunde et al. 2007; Gerstberger et al. 2014; Corley et al. 2020).

Besides the well-defined globular domains, some RNPs consist partially or entirely of low complexity (LC) sequences including Arg-Gly-Gly (RGG) and Arg-Ser (RS) repeats as well as positive Lys/Arg (K/R) patches (Balcerak 2019). Many of these LC proteins can phase separate and are a component of membrane-less RNP granules, where they serve as platforms for protein-protein or protein-RNA interactions (Chong et al. 2018). Whereas most often RGG and RS repeats engage in low-affinity, nonspecific interactions, there are examples of high-affinity interactions and cofolding with target RNAs (Phan et al. 2011). Other examples of noncanonical RBD interactions can be found within large RNPs such as preribosomal particles, ribosomes, and spliceosomes. With the recent X-ray and cryo-EM

(C) 2021 Vaishali et al. This article, published in RNA, is available under a Creative Commons License (Attribution-NonCommercial 4.0 International), as described at http://creativecommons.org/licenses/ by-nc/4.0/. 
structures of the eukaryotic ribosome, it has become clear that, in contrast to their prokaryotic counterparts, many eukaryotic ribosomal proteins have long insertions that are either unstructured or form extended helices which make contacts with the ribosomal RNA (Ben-Shem et al. 2011; Klinge et al. 2011, 2012).

Earlier, RBPs were identified using biochemical methods such as UV crosslinking, followed by RNA affinity purification and identification of the bound proteins by immunoblotting or mass spectrometry (Dreyfuss et al. 1984; Pinol-Roma et al. 1988; Gerstberger et al. 2014). With the advent of whole-genome sequencing, and the determination and deposition of high-resolution structures in the protein data bank (PDB), new candidate RNA binding proteins were put forward through multiple sequence alignment and computational predictions (Gerstberger et al. 2014). During the last decade, a variety of in vitro and in vivo approaches have been developed to identify the complete set of RNA binding proteins (Castello et al. 2016b; Ryder 2016; Perez-Perri et al. 2018). To date, such RNA interactome capture approaches have been performed in diverse cell types, tissues, and organisms (Baltz et al. 2012; Castello et al. 2012, 2016b; Mitchell et al. 2013; Ryder 2016; Hentze et al. 2018). In essence, these methods involve in vivo UV crosslinking of RBPs to RNA, followed by oligo(dT) pulldown under denaturing conditions to isolate poly-adenylated RNA species, and mass spectrometry (MS) in order to identify the crosslinked proteins (Dimitrova-Paternoga et al. 2020). Overall, these studies demonstrated that the number of RNA bound proteins can reach up to $10 \%$ of the organism's proteome in some species (Gerstberger et al. 2014; Hentze et al. 2018). Moreover, about half of the identified proteins lacked classical RNA binding domains and many did not even have previously known functions related to RNA (Hentze et al. 2018). Subsequently, a few of these proteins were tested and validated to be bona fide RNA binding proteins, for example p62 or the TRIM family proteins Brain tumor and TRIM25 (Loedige et al. 2014, 2015; Choudhury et al. 2017; Horos et al. 2019; Haubrich et al. 2020). Of note, a verified RBP is the cytoskeletal protein APC (Adenomatous polyposis coli). APC possesses a basic stretch that was demonstrated to bind to and promote localization of $\beta 2 B$ tubulin mRNA to the plus ends of growing microtubules (MTs) in neurons (Preitner et al. 2014).

Interestingly, another cytoskeletal protein, End-Binding Protein 1 (EB1), also known to interact with APC, was identified as a novel putative RBP in two independent mRNA interactome capture studies in Drosophila (Sysoev et al. 2016; Wessels et al. 2016). EB1 is an evolutionarily conserved protein that binds to the plus ends of MTs in a nucleotide dependent manner and regulates the plus end dynamics (Vaughan 2005; Nehlig et al. 2017). EB1 also plays important roles in recruiting other MT associated proteins (such as CLIP-190) to the plus end of MTs
(Dzhindzhev et al. 2005). Studies in Drosophila S2 cells revealed that EB1 depletion causes a spectrum of MT associated defects, such as reduced microtubule dynamics, a drastic reduction in astral MTs, malformed mitotic spindles, defocused spindle poles, and mis-positioning of spindles away from the cell center (Rogers et al. 2002). Similar phenotypes were observed in mitotic spindles of Drosophila embryos microinjected with anti-EB1 antibodies (Rogers et al. 2002). EB1 thus appears to have a crucial role in regulation of MT dynamics, which in turn are essential for cellular processes such as cell cycle, transport and localization of RNA and proteins, vesicle transport and establishment of cell polarity, all of which rely on a proper MT network and dynamics. Owing to these important roles of EB1 in regulating MTs in vivo, it is of interest to determine if the protein interacts directly with RNA and, if so, to study the physiological significance of the interaction in vivo.

Consequently, we chose EB1 as one of six putative RBPs to be validated for their RNA binding properties in this study. The choice of the five other target RBPs was based on (i) being hits in mRNA interactome capture, (ii) possible additional availability of RNA binding related data, (iii) amenability for NMR spectroscopy (smaller full-length protein or RNA binding has been assigned to a smaller domain). Thus, we chose the following metabolic and regulatory enzymes: human Thioredoxin, hsTXN; yeast FK506-binding protein 1, scFPR1, and human tripartite motif protein 25, hsTRIM25; an adapter protein (human Beta-1-synthrophin, hsSNTB1), and one other cytoskeletal protein, (Drosophila atypical Tropomyosin1 [aTm1]). These candidates are described in more detail below.

As a primary tool, we chose nuclear magnetic resonance spectroscopy (NMR) to validate the RNA binding properties of the six putative RBPs, due to its high sensitivity to changes in the chemical environment of protein residues upon interaction with ligands (in this case RNA). As a result, even extremely weak interactions can be studied using NMR. This is of special importance as we do not know whether the RBPs of interest possess certain sequence specificity. Three of the proteins did not show any chemical shift perturbations (CSPs) upon RNA titration, whereas the other three did to varying degrees. One of the proteins for which CSPs indicated a weak interaction with the RNA tested was EB1. CSP analysis and further competition assays demonstrated that RNA interacts with EB1's microtubule binding surface. To understand the physiological significance of this interaction we performed RNA immunoprecipitation (RIP) with GFPtagged EB1 from Drosophila oocytes. Verification of some of the most enriched targets by colocalization analysis and EB1 knockdown indicate that EB1 is rather an opportunistic RNA binder. As it stands, we propose to categorize novel RBPs devoid of a classical RNA binding domain into independent, dependent, and opportunistic RBPs. 


\section{RESULTS}

\section{NMR titration studies of six RBPs with poly(U) oligo RNA}

In order to obtain biophysical evidence of direct RNA binding, we performed NMR-monitored RNA titrations of putative RBPs lacking a canonical RNA-binding domain, selected from hits of RNA interactome studies in yeast, Drosophila and mammalian cell lines. We selected TXN and SNTB1, as data exist regarding their putative RNA binding surfaces and it would be relatively straightforward to confirm these surfaces by NMR. We expressed fulllength proteins (dmEB1, scFPR1, hsTRX) or domains, to which RNA binding has been assigned (TRIM25-PRY/ SPRY domain, hsSNTB1's PDZ domain, and the N-terminal domain of Drosophila aTm1) in E. coli, using culture medium containing ${ }^{15} \mathrm{NH}_{4} \mathrm{Cl}$ as the sole nitrogen source. The purified ${ }^{15} \mathrm{~N}$-labeled proteins were then titrated with synthetic RNA and HSOC spectra were recorded to detect possible interactions. As the RNA targets of the proteins are unknown, we used short poly-(U) oligomers in the initial experiments. These oligomers also serve as a good starting point because the RNA interactome studies use proteinRNA crosslinking, which only occurs between protein residues and nonpaired RNA bases. At each titration point we collected a ${ }^{1} \mathrm{H},{ }^{15} \mathrm{~N}-\mathrm{HSOC}$. This experiment resolves each amide proton/amide nitrogen correlation in the backbone and the proton-nitrogen correlation in side chains of asparagines, glutamines and tryptophans as a single cross peak. Although the spectrum itself contains no readily extractable structural information, it is sensitive to even minor changes in the conformation and chemical environment of amino acids. Upon titration, spectral changes such as chemical shift perturbations (CSPs), line broadening and resulting signal loss are therefore very sensitive indicators of even weak and transient interactions. The induced dose-dependent CSPs, corresponding to fast exchange, also allows the determination of binding affinity, and this is often observed for single classical RNA binding domains like RRMs, KH domains, or CSDs and dsRBDs (Ankush Jagtap et al. 2019; Hollmann et al. 2020)

\section{Thioredoxin (TXN)}

TXN is a highly conserved enzyme which catalyzes the reduction of disulfide bonds and plays a critical role in the maintenance of redox homeostasis (Lee et al. 2013). The protein was identified in human and $S$. cerevisiae mRNA interactome studies as a putative RBP (Castello et al. 2012; Beckmann et al. 2015). Moreover, the potential RNA-binding interface was suggested to involve two conserved lysines ( $\mathrm{K} 3$ and $\mathrm{K} 8$ ) in the amino-terminal region, with $\mathrm{K} 8$ being at the start of $\alpha$-helix $\alpha 1$ (Castello et al. 2016b). Addition of a poly(U) 8-mer at an excess of five equivalents to the protein did not induce any CSPs in its
${ }^{15} \mathrm{~N},{ }^{1} \mathrm{H}$-HSOC NMR spectrum (Fig. 1A). We extended the investigation by two more titrations with poly $(A)$ and poly (C) 8-mers to test whether TXN could have specificity toward other bases. Again, CSPs could not be observed (Supplemental Fig. S1A). Although even a nonspecific single-stranded RNA should induce CSPs for a weak RNA binder, to study the possibility of TXN binding to RNA in a structured context, we titrated TXN with yeast tRNA, which should provide a large variety of single-, doublestranded regions and structural features. However, we observed no changes in the spectra, even in the presence of a large excess of tRNA (Supplemental Fig. S1A). The absence of any shifts led us to conclude that TXN on its own in an isolated, in vitro context does not bind RNA.

\section{FK506-binding protein 1 (scFPR1)}

scFPR1 (FK506-binding protein or FKBP12 in human) is a peptidyl prolyl isomerase (PPI) identified in a yeast mRNA interactome study (Beckmann et al. 2015). The human ortholog FKBP12 is a target of the immunosuppressants FK506 and rapamycin (Hausch et al. 2013; Kolos et al. 2018). Similar to TXN, neither addition of 2.4 molar excess of a poly(U) 9-mer, nor addition of yeast tRNA at a molar excess of fivefold induced any CSPs (Fig. 1B; Supplemental Fig. S1B). Of note, tRNA was suggested to be the RNA target of FPR1 based on enhanced (eCLIP) experiments (M Sun, unpubl.). For comparison, we titrated rapamycin, which has been demonstrated to be a bona fide ligand of scFPR1. Here, clear CSPs were observable, excluding the possibility that the protein used for the RNA titration experiments was inactive (Supplemental Fig. S1C). Thus, we conclude that scFPR1 is also not an RBP in an isolated, in vitro context.

\section{Syntrophin-beta-1 (hsSNTB1)}

Syntrophins form a group of adapter proteins that link a variety of ion channels and signaling proteins to the dystrophin complex at neuro-muscular junctions (NMJ) (Belhasan and Akaaboune 2020). They feature two PH (Pleckstrin homology) domains, flanking a PDZ (PSD-95/ Dlg/ZO-1) domain, and a unique carboxy-terminal syntrophin domain (SU). Like Thioredoxin, Beta-1-syntrophin (SNTB1) and closely related SNTB2 were identified as novel RBPs in a HeLa cell mRNA interactome study (Castello et al. 2016a). Moreover, a putative RNA-binding site was mapped subsequently to a basic cavity formed by the second and third $\beta$-strands and a short helical element in between (Castello et al. 2016b). Therefore, we focused on the PDZ domain of SNTB1 for further analysis and added a poly(U) 8-mer oligomer RNA up to a five molar excess. Yet again, no CSPs were observed. We also tested poly (C) 8-mer for which no CSPs could be observed. For poly (A) 8-mer, however, five resonances showed small CSPs. Binding is very weak and estimated to be in the millimolar 
A

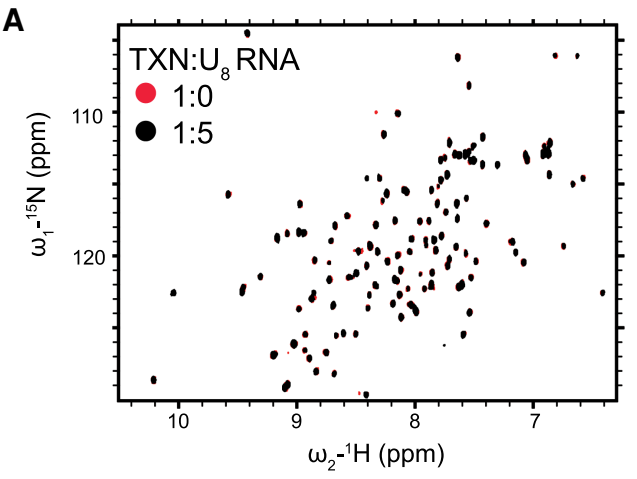

C

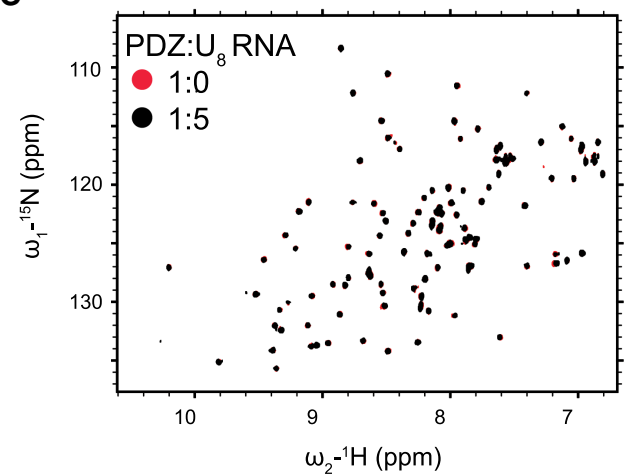

D

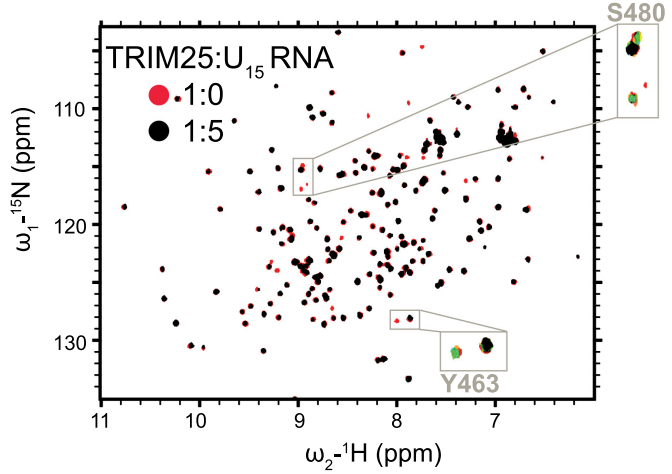

F

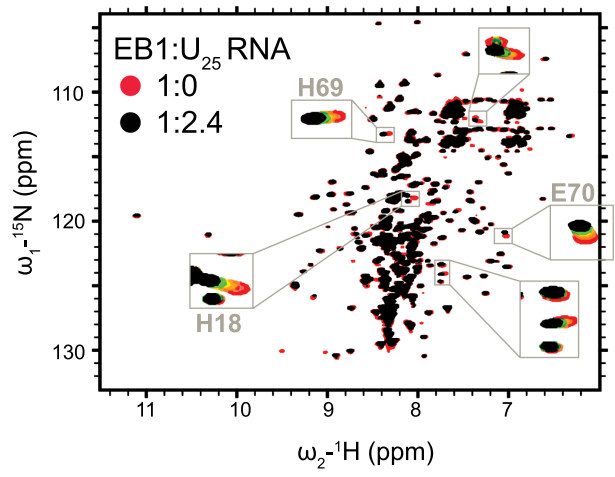

B
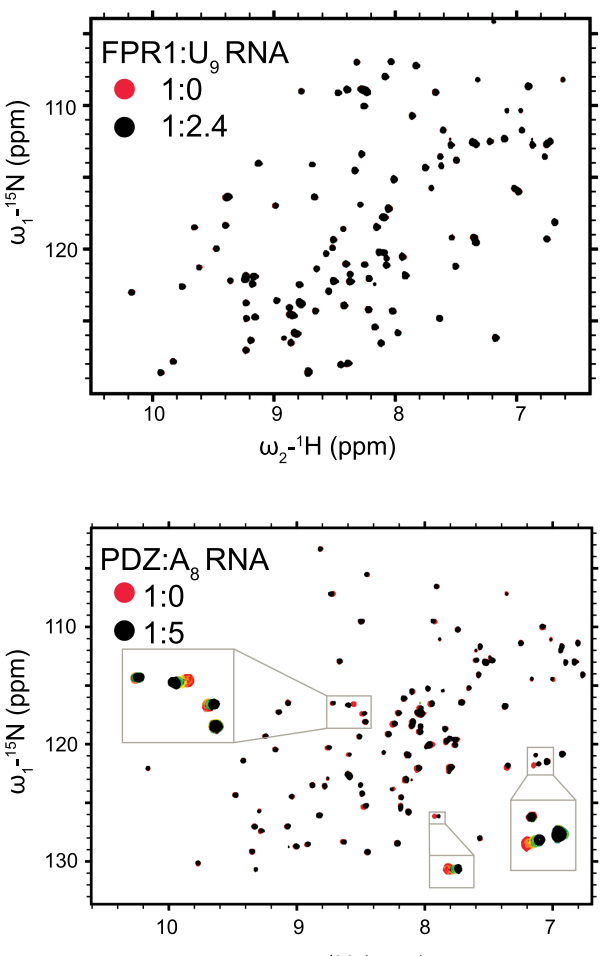

$\omega_{2}-1 \mathrm{H}(\mathrm{ppm})$

E

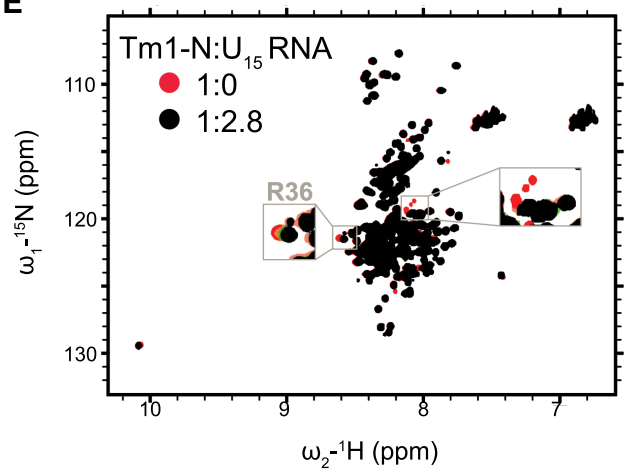

FIGURE 1. Interaction of novel RBPs with RNA. (A) ${ }^{1} \mathrm{H} /{ }^{15} \mathrm{~N}-\mathrm{HSOC}$ spectra of $h s T X N$ titrated with poly(U)-8-mer; (B) scFpr1 titrated with poly(U)-9mer; ( $C$, left) hsSNTB1-PDZ domain titrated with poly(U)-8-mer; (C, right) and poly(A)-8-mer; (D) hsTRIM25-SPRY domain titrated with poly(U)-15mer; (E) aTm1-N domain (I/C isoform) titrated with poly(U)-15-mer; (F) and dmEB1 titrated with poly(U)-25-mer. The spectra of the free proteins (in red) are overlaid with the spectra of proteins titrated with RNA (in black). The $\mathrm{x}$-axis corresponds to the ${ }^{1} \mathrm{H}$ dimension whereas the $y$-axis corresponds to the ${ }^{15} \mathrm{~N}$ dimension. Each peak represents an $\mathrm{NH}$ bond and depicts an individual residue. The ratio of protein to RNA is also shown. For EB1, Tm1, and TRIM25, full titration points for selected residues are shown in zoomed insets (protein:RNA = 1:0/0.2/0.6/1/1.6/2.4 [EB1]; 1:0/0.2/ 0.6/2/2.4/2.8 [Tm1]; 1:0.15/0.6/1.2/2.5/5 [TRIM25]; 1:0.5/1/2/3/4/5 [PDZ]; 1:1/2/3/4/5 [TRX] ratios). 
range. The magnitude of the CSP between the fourth and last titration point was as large as in the two previous titration steps and is far from saturated even at a ratio of 1:5 (protein : RNA). Thus, binding is too weak to be of physiological relevance. On the other hand, the base specificity suggests that there are more than unspecific transient charge-charge interactions, as CSPs should have been observed in this case also for poly $(U)$ and poly $(C)$. We conclude that the PDZ domain of SNTB1 could bind RNA in a cellular context as part of an RNP complex and falls into the category of a dependent RBP.

\section{Tripartite motif protein 25 (TRIM25)}

TRIM25 is a ubiquitin E3 ligase involved in cell cycle regulation, organ development and innate immunity (Orimo et al. 1999; Zhang et al. 2015a; Lee et al. 2018). It is a member of the TRIM protein family characterized by a tripartite motif at its amino terminus containing a RING domain, two B-Box domains and a coiled-coil region. The carboxy-terminal region can feature a diverse set of domains in the TRIM family. TRIM25 belongs to the PRY/SPRY subfamily of TRIM proteins and thus carries a carboxy-terminal PRY/SPRY domain (Williams et al. 2019). Besides being identified and validated as an RBP in genome-wide screens (Kwon et al. 2013; Castello et al. 2016b), several biochemical studies in vitro have also reported RNA binding by TRIM25 (Manokaran et al. 2015; Choudhury et al. 2017; Choudhury and Michlewski 2019). By now, the ability of TRIM25 to bind to a number of RNAs is well established (Kwon et al. 2013; Manokaran et al. 2015; Choudhury et al. 2017; Meyerson et al. 2017; Lin et al. 2019), However, there is still some uncertainty about which part of the protein is required for RNA binding. Whereas most studies appear to confirm an important role of the PRY/SPRY domain in RNA binding (Castello et al. 2016a; Choudhury et al. 2017), the original work of Kwon et al. (2013), and at least two subsequent studies also indicate direct RNA binding to the coiled-coil domain (Kwon et al. 2013; Lai et al. 2019; Haubrich et al. 2020). PRY/ SPRY domains are typically protein-protein interaction domains covering a wide spectrum of substrates, ranging from linear peptide epitopes to multiprotein assemblies such as antibodies or viral capsids. The domain consists of a $\beta$-sandwich with a highly conserved core and several poorly conserved, flexible loops accommodating the substrate binding sites (Song et al. 2005). As opposed to TXN, scFPR1, and SNTB1, NMR resonances of TRIM25 exhibited clear CSPs upon addition of five molar equivalents of poly $(U)$ 15-mer RNA, confirming its ability to bind singlestranded RNA with a dissociation constant in the high micromolar range [poly(U)-15-mer, Fig. 1D, data cannot be reliably fitted due to the weak chemical shift perturbations]. Interestingly, we observed binding to two distinct regions of the PRY/SPRY domain (residues 456-511 and
549-605) of which only one was previously identified by RBDmap in (Choudhury et al. 2017) (residues 470-508). In follow-up NMR studies and a detailed biophysical characterization of the RNA binding of TRIM25 that has been published in the meantime (Haubrich et al. 2020), we could show that these binding sites on the PRYSPRY domain have distinct preferences for single- and double-stranded RNA and thereby mediate structure specific binding to stem-loop RNAs. Additionally, we could also confirm that the coiled-coil binds to RNA synergistically with the PRY/SPRY domain. TRIM25 binding by RNA has an effect on RIG-I ubiquitination and the interferon response, suggesting an involvement of RNA in the host defense against viral infection (Haubrich et al. 2020).

\section{Atypical Tropomyosin1 (aTm1)}

Drosophila melanogaster atypical Tropomyosin1 (aTm1) is a unique isoform of the actin-binding protein Tropomyosin 1 (isoform I/C), and has a role in recruitment of the motor protein Kinesin-1 to oskar mRNA in the Drosophila oocyte (Veeranan-Karmegam et al. 2016; Gáspár et al. 2017a). aTm1 comprises a unique, unstructured $\mathrm{N}$ domain, and it was suggested that the protein might directly interact with RNA (Gáspár et al. 2017a). In addition, Tm1 peptides were identified in an mRNA interactome capture study from Drosophila embryos (Sysoev et al. 2016), although the isoform from which they originated is unknown. Upon addition of a poly(U) 15-mer RNA oligomer to the disordered amino-terminal domain (aa 1-247) in a 1:2.8 ratio, we could observe CSPs and line broadening of NMR signals, clearly indicative of RNA binding (Fig. 1E) with a dissociation constant of $20 \mu \mathrm{M}$. After backbone assignment, the largest CSP could be assigned to residue R36. The functional significance and a detailed structural and biochemical characterization have been published elsewhere (Dimitrova-Paternoga et al. 2021).

\section{End binding protein 1 (EB1)}

As mentioned in the introduction, EB1 was identified as a novel putative RNA binding protein in two independent mRNA interactome capture studies in Drosophila (Sysoev et al. 2016; Wessels et al. 2016). Structurally, EB1 is a 33 $\mathrm{kDa}$ protein and consists of an amino-terminal Calponin Homology $(\mathrm{CH})$ domain and a carboxy-terminal EBHomology (EBH) coiled-coil domain, connected by a linker region (Fig. 2A; Akhmanova and Steinmetz 2008). The CH domain is known to be involved in microtubule binding, and the EBH domain is crucial for EB1 homodimerization and interaction with other proteins (Akhmanova and Steinmetz 2008). We titrated a poly(U) 25-mer RNA oligomer into full-length EB1 and observed clear CSPs in the fast exchange regime, which could be fitted to a dissociation constant in the high $\mu \mathrm{M}$-range. Thus, EB1 could also be confirmed as an RBP in vitro. 
A

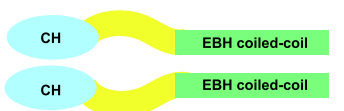

B

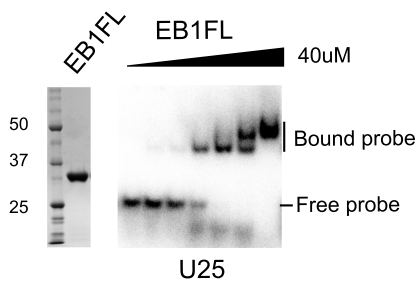

D

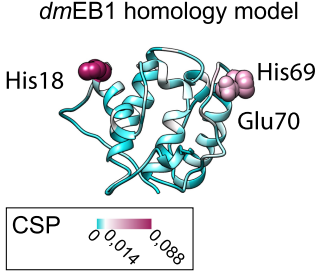

F

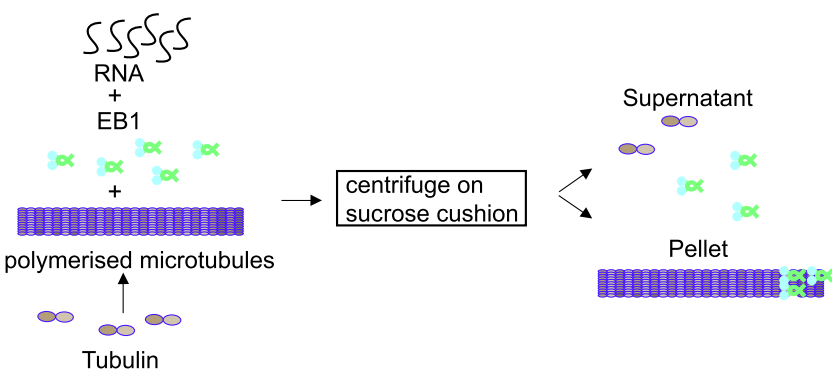

C

E
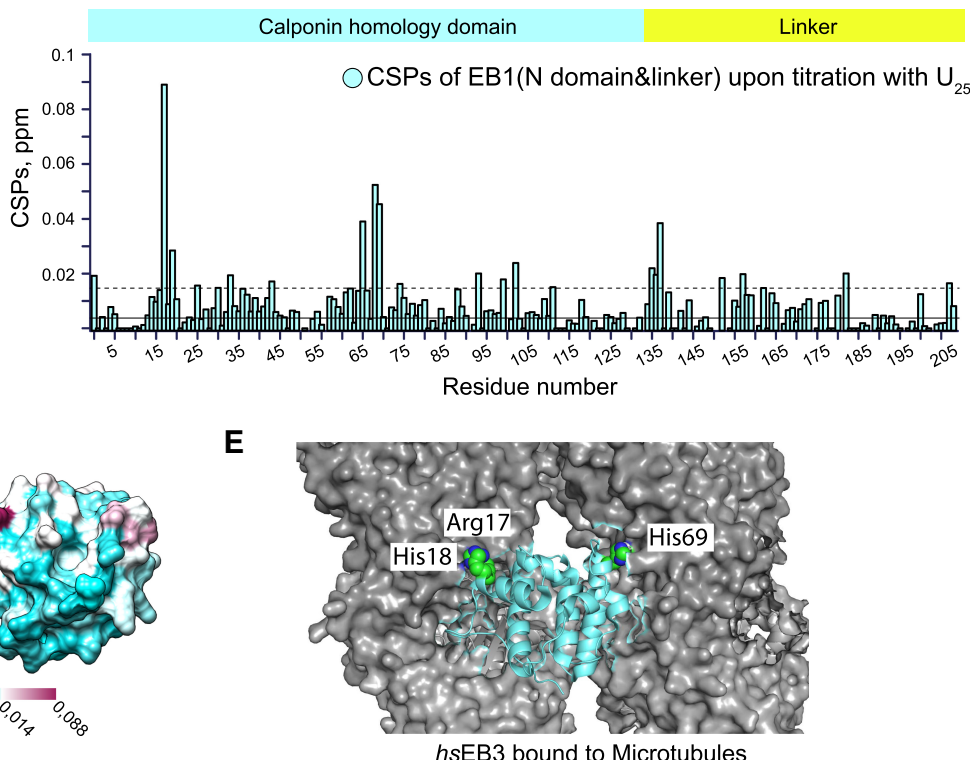

hsEB3 bound to Microtubules

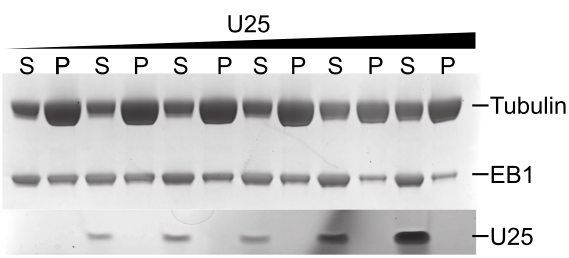

FIGURE 2. EB1 interaction with RNA involves its MT binding surface. (A) A schematic of EB1 domain organization: EB1 comprises a calponin homology domain $(\mathrm{CH})$ and an EB1-homology $(\mathrm{EBH})$ coiled-coil domain connected by a linker region; (B) EB1 binds RNA in vitro: EMSA of recombinant dmEB1 (left panel) with ${ }^{32} \mathrm{P}$-labeled poly(U) 25-mer (lower panel). EB1 $(0,5 ; 1 ; 5 ; 10 ; 20 ; 40 \mathrm{mM}$ protein) was mixed with $2.5 \mathrm{nM}$ of ${ }^{32} \mathrm{P}$-labeled poly(U) 25-mer. The first lane is probe alone control; $(C)$ CSPs along the EB1 N + linker region upon titration with poly(U) 25-mer; (D) CSPs are plotted on the homology model of the $d m E B 1 N$ domain in ribbon (left panel) and surface (right panel) representations. (E) Interaction of EB1 with RNA maps to the same surface with which EB1 interacts with MTs: hsEB3 bound to microtubules based on 3JAL (Zhang et al. 2015b); (F) RNA competes with MTs for binding to EB1: Cosedimentation of EB1 with MTs and RNA. EB1 alone or preincubated with increasing concentrations of poly(U) 25-mer were added to polymerized microtubules (left panel). After incubation, ultracentrifugation over a sucrose cushion was performed, followed by separation of the pellet and supernatant fractions. The proteins and RNA were separated on SDS PAGE and on urea denaturing gel, respectively (right panel).

In summary, half of the proteins tested could not be confirmed as independent RBPs in an isolated context, whereas the other half did show RNA binding in vitro. Of special interest was the confirmed RNA binding of EB1, as this protein shows the strongest CSPs, though the interaction was rather weak, as indicated by the fact that the CSPs were not saturated even at an excess of 2.4 molar equivalents of RNA. Therefore, we decided to further investigate RNA binding by EB1 in order to gain insight into its functional relevance.

\section{The microtubule binding surface of EB1 interacts with RNA}

Titration of EB1 with poly(U) 25-mer RNA triggered CSPs in the fast exchange regime of NMR, demonstrating an inter- action between the protein and RNA. We further confirmed this interaction using electrophoretic mobility shift assay (EMSA) as an additional biochemical approach in vitro. Adding EB1 in increasing concentrations to ${ }^{32} \mathrm{P}$-labeled poly(U) 25-mer RNA probe gradually shifted the probe to higher molecular weight species, corroborating the interaction of EB1 with poly(U) 25-mer (Fig. 2B).

In order to determine the RNA binding interface on EB1, we sought to identify the residues showing the strongest CSPs upon titration. To this end, we performed standard triple resonance backbone assignment of the calponin homology domain attached to the linker region of EB1 (Fig. 2A). Because of a good overlap between the ${ }^{1} \mathrm{H}^{15}{ }^{15} \mathrm{~N}$ HSOC spectra of EB1 full length and EB1N domain and linker region (data not shown), we could transfer the 
assignments to EB1 full length and plot the CSPs induced by RNA binding versus the residue number. We observed changes in three main patches-around His 18 and His69 of the calponin homology domain, and around Gly138 at the beginning of the linker region (Fig. 2C). Next, we plotted the changes onto a homology structure model of the $\mathrm{CH}$ domain of dmEB1 generated by Phyre2 (Kelley and Sternberg 2009). Interestingly, the CSPs map along a continuous surface that has been shown to be essential for the interaction of EB1 with MTs (Fig. 2D,E; Zhang et al. 2015b).

The observation of a shared binding surface for RNA and MTs suggested that these might compete for the same binding site on EB1. To test this, we performed a cosedimentation assay (Venkei et al. 2006) (Fig. 2F), in which tubulin was polymerized into MTs in the presence of GTP $\gamma \mathrm{S}$ (a nonhydrolysable analog of GTP, providing a preferential state for EB1 binding [Maurer et al. 2011]), and then incubated with a complex of EB1 and increasing concentrations of poly(U) 25-mer. Upon loading on a sucrose cushion and centrifugation, MTs accumulate in the pellet fraction together with bound EB1 and/or RNA, whereas free EB1 protein and RNA remain in the supernatant fraction (Fig. 2F, schematic). Comparison of the pellet and supernatant fractions at each RNA concentration showed that with increasing quantities of RNA, the amount of EB1 pelleting with MTs decreased. This indicates that binding of EB1 to RNA and MTs is mutually exclusive (Fig. 2F, right panel). As can be seen, the quantity of microtubules in the pellet also decreases as the amount of RNA added increases, which can be attributed to our observation that EB1 appears to stimulate microtubule polymerization (Supplemental Fig. S2). Lack of binding of EB1 results in reduced polymerization of microtubules under the same conditions, leading to an eventual decrease of microtubules in the pelleted fraction and an increase of tubulin in the supernatant fraction (Supplemental Fig. S2).

\section{EB1 binds opportunistically to RNA in vivo}

To understand the physiological significance of RNA binding by EB1, we aimed to identify the targets of EB1 in vivo. To this end, we performed an RNA-immunoprecipitation and sequencing (RIP-seq) experiment in flies expressing EB1-GFP, by pulling down UV cross-linked EB1-GFP-RNA complexes from Drosophila oocytes using anti-GFP antibody. RNAs so obtained were extracted and, following library preparation, subjected to sequencing. This led to the enrichment of 1017 genes in the EB1-GFP sample vs GFP control with a $P$-value $>0.01$. Out of these, based on $\mathrm{GO}$ term analysis for involvement in transport, localization, cell cycle and related functions, 12 candidates were selected for further validation (Fig. 3A). We also analyzed the expression levels of the enriched genes and found that out of the total 1017 genes enriched, only 220 had an RPKM > 51, indicative of high expression as per the modENCODE ex- pression level bins (Gelbart and Emmert 2013). For the candidates selected for further studies, two of these (asp and chc) are considered to be highly expressed (RPKM > 51), and two others (drosha and synj) show expression levels with RPKM values between 26 to 50 . All the rest are moderately/lowly expressed.

To check if these target RNAs colocalize with EB1 in vivo, we performed single molecule fluorescence in situ hybridization (smFISH) of the target RNAs in oocytes of flies expressing EB1-GFP. The frequency of their colocalization with EB1-GFP was then determined. Since oskar mRNA, which is one of the most highly expressed RNAs in the Drosophila oocyte (Brown et al. 2014), was not enriched in the RIP-seq data set, we used this mRNA as a negative control (Fig. 3B). Clathrin heavy chain mRNA (Chc) and Adenomatous polyposis coli mRNA (Apc) showed the highest frequency of colocalization at $10.2 \%$ and $9.8 \%$, respectively, as compared to $5 \%$ for oskar mRNA, implying a relatively low frequency of colocalization of EB1-GFP with the top candidate RNA hits. We also used S2 cells, which offer a better resolution, to perform colocalization analysis of three of the top hits (chc, Dynein heavy chain 64c mRNA [Dhc64c] and mini spindles mRNA [msps]) with EB1-GFP. We did not detect any colocalization of EB1 with the candidate target RNAs in S2 cells either (Supplemental Fig. S2A). This implies that EB1 binds rather nonspecifically to RNA and, possibly, that the RNAs which get crosslinked do so as a result of their shared subcellular localization with EB1.

Another notable feature of four of the chosen target RNAs that showed a higher frequency of colocalization with EB1 was their particular localization pattern in the oocyte. Abnormal spindle (asp), msps, and chc displayed an anterior localization similar to EB1-GFP, whereas dhc64c formed foci in the nurse cells. To see if EB1 plays a role in these localization patterns, we knocked down EB1 and assessed the distribution of the candidate RNAs. Efficiency of the knockdown in the germline was confirmed by smFISH using eb1-specific probes (Supplemental Fig. S2B). However, we observed no change in the distribution of any of the RNAs, suggesting that EB1 is not essential for their intracellular localization.

Taken together, these data suggest that the binding of EB1 to RNA is rather opportunistic and may not be functionally relevant. However, these experiments do not exclude the possibility that RNA might regulate the function of $E B 1$, rather than EB1 the function of RNA.

\section{DISCUSSION}

In recent years, extensive RNA interactome capture studies have shown that a large number of proteins without classical RNA binding domains bind directly to RNA. Here, utilizing the sensitivity of NMR to even very weak and transient interactions, we were able to test binding of several novel RBPs with unknown RNA targets. This has 
A

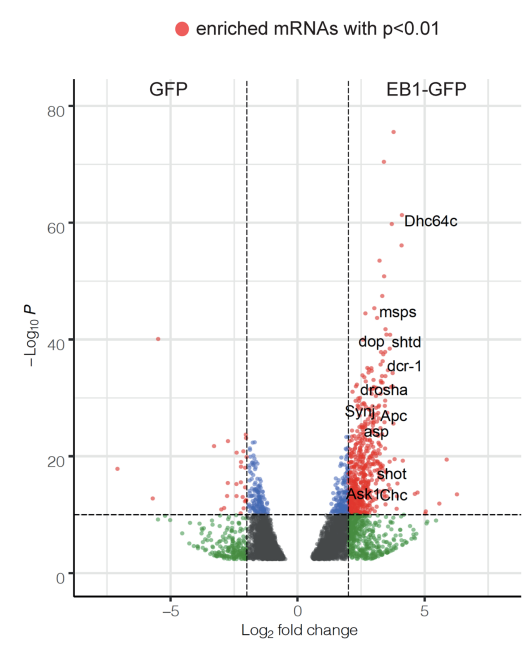

B

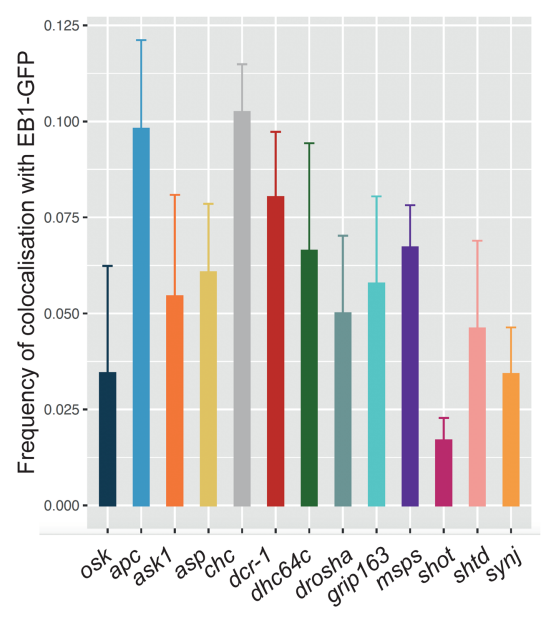

C
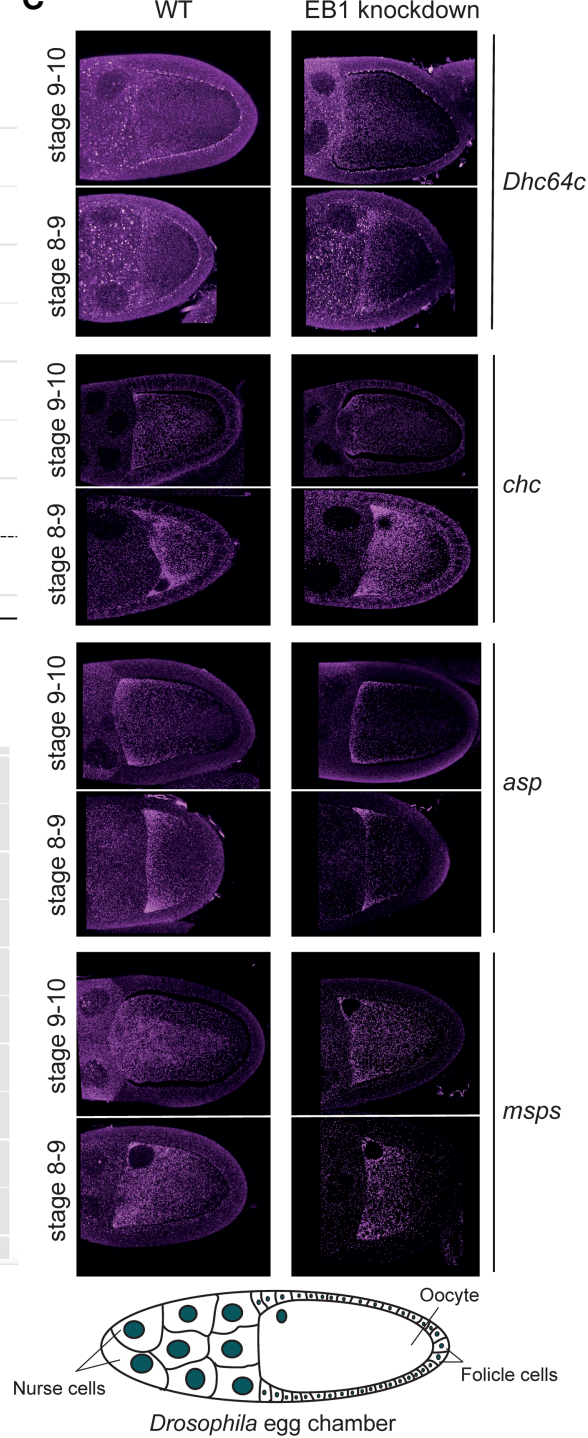

EB1 knockdown
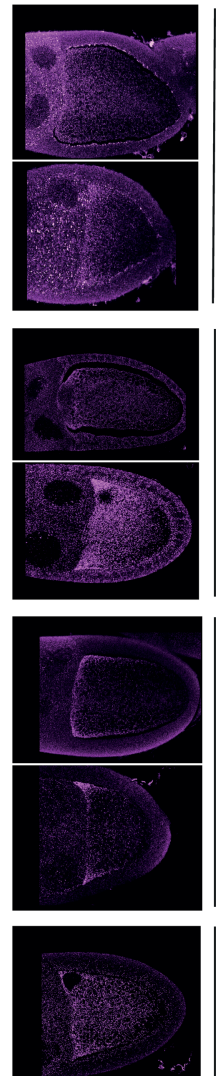

msps

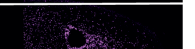

P

3.

\section{chc}

asp

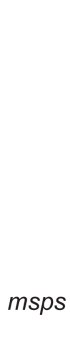

\section{.}




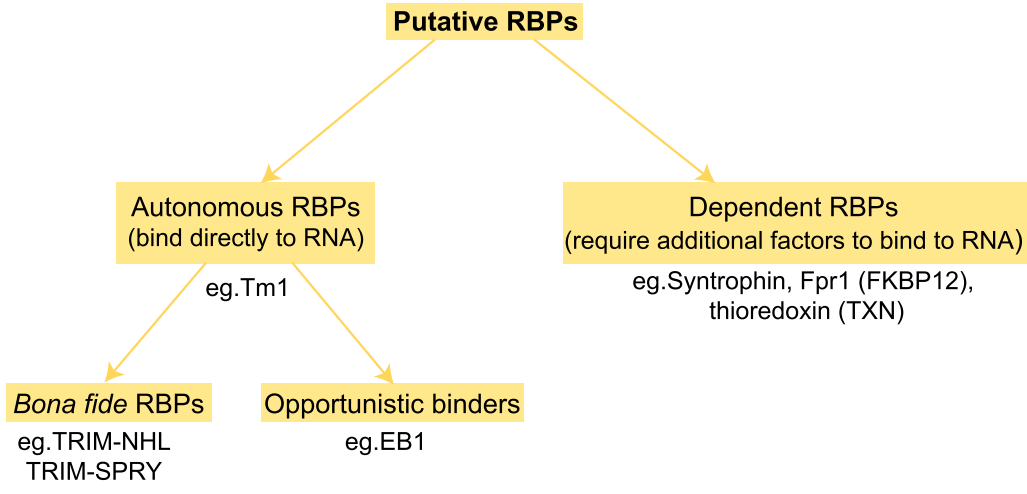

FIGURE 4. Classification of novel RNA binding proteins. Novel RBPs can be classified in two main groups: Autonomous binders such as EB1, Tm1, TRIM-NHL, and at least some TRIMSPRY proteins which bind RNA directly. The recurring validation of their RNA binding properties in individual studies changes their status from being a novel RBP to being a classical, general RBP. Others, like Thioredoxin (TXN), SNTB1, or FKBP12, however, can bind RNA only dependent on other factors present in vivo. It cannot be dismissed at the moment that they might not bind RNA altogether. And finally, it remains to be confirmed if proteins like EB1 which bind RNA in vitro do so in a functional relevant way in vivo.

Firstly, the top hits from RIP-seq exhibited relatively low frequency of colocalization with EB1-GFP in vivo. Secondly, EB1 knockdown did not show any significant phenotypic change in the flies. All this makes it difficult to assume or decipher any meaningful interaction of the candidates with EB1 in vivo. However, there is a second EB1-like uncharacterized protein, CG18190, which directly interacts with EB1 (data not shown) and it can very well be that this protein compensates for the lack of EB1 when it is knocked-down in the oocyte. Further analysis will be necessary to disentangle the relationship of these two homologs and a putative role of CG18190 in RNA metabolism.

Another aspect we could not address with our experiments is the possibility of RNA regulating the function of EB1 rather than the reverse. Some recent studies have shown an active function of RNA in the regulation of certain proteins. For example, the small vault RNA regulates autophagy by controlling the oligomeric state of the p62 protein (Horos et al. 2019). In another study Huppertz et al. demonstrated that RNA can regulate the enzymatic activity of the glycolytic enzyme enolase 1 (ENO1) (Huppertz et al. 2020). Therefore, we cannot exclude the possibility that RNA might regulate the function of EB1. It is possible that by competing with the microtubules for the same binding surface on EB1, RNA might exert an effect on cytoskeletal organization.

In summary, we showed that some novel RBPs without classical RNA binding domains do indeed bind RNA, but others do not in an isolated context. We therefore encourage and recommend a thorough in vitro assessment of RNA binding properties of the protein of interest before embarking on time consuming and elaborate functional studies.

\section{MATERIALS AND METHODS}

\section{Protein expression and purification}

Full-length human TXN and SNTB1 PDZ domain (residues 111-196) were cloned into PETM11 and expressed in E. coli $B L 21(D E 3)$. Expression was induced with $0.2 \mathrm{mM}$ IPTG at $\mathrm{OD}_{600}=0.6$ at $18^{\circ} \mathrm{C}$ and cells harvested after $18 \mathrm{~h}$. The protein was purified by Ni-NTA affinity chromatography in $50 \mathrm{mM}$ Tris, $\mathrm{pH} 7.5,300 \mathrm{mM}$ $\mathrm{NaCl}, 1 \mathrm{mM}$ TCEP and eluted with a gradient of imidazole (10-300 mM). The $\mathrm{His}_{6}-$ tag was cleaved by TEV protease and removed by a second passage over the $\mathrm{Ni}$ NTA column.

Stable isotope labeled TRIM25 PRY/ SPRY was expressed as previously described (Koliopoulos et al. 2018). Briefly, residues 439-630 were subcloned into pETM22 and coexpressed with KJE, ClpB, and GroELS in E. coli BL21(DE3) (de Marco et al. 2007) in M9 media, supplemented with ${ }^{15} \mathrm{~N}$-labeled ammonium chloride (Cambridge isotopes) (induction with $0.2 \mathrm{mM}$ isopropyl $\beta$-D-1-thiogalactopyranoside [IPTG] at $\mathrm{OD}_{600}=0.6$ followed by expression at $18^{\circ} \mathrm{C}$ for $22 \mathrm{~h}$ ). The protein was purified by Ni-NTA affinity chromatography and the tag was cleaved by $3 \mathrm{C}$ protease and removed by ion exchange.

Full-length dmEB1 and scFPR1 were cloned between Ndel and BamHI sites of pET24d-His6-Tev plasmid (see Dimitrova et al. 2015). dmTm1 (residues 1-247) was cloned between BamHI and Sacl sites of pETM11-His-SUMO plasmid (https://www.embl.de/ pepcore/pepcore_services/strains_vectors/vectors/bacterial_exp ression_vectors/popup_bacterial_expression_vectors/). ${ }^{15} \mathrm{~N}$-labeled proteins were expressed in E. coli BL21 (DE3) CodonPlusRIL cells in M9 media after induction with IPTG at $18^{\circ} \mathrm{C}$ for 16 h. Cells were lysed in $20 \mathrm{mM}$ Tris- $\mathrm{HCl}, \mathrm{pH} 7.5 ; 500 \mathrm{mM} \mathrm{NaCl}$, $0.01 \%$ NP-40, 5\% glycerol, 40 mM imidazole buffer supplemented with Protease Inhibitor Cocktail (Roche) and $5 \mathrm{mM} \beta$-mercaptoethanol. The proteins were purified by $5 \mathrm{~mL}$ Ni-NTA columns (GE Healthcare) and eluted over an imidazole gradient (40-600 $\mathrm{mM})$. After cleavage of the tag by TEV protease in the case of EB1 and FPR1 or by Senp2 in the case of Tm1-I/C, EB1 and FPR1 were further purified over Mono $\mathrm{Q}$ ion exchange column (GE Healthcare) or Ni-NTA column for Tm1.

Prior to NMR measurements, for all proteins the buffer was exchanged to $20 \mathrm{mM}$ sodium phosphate, $\mathrm{pH} 6.5,150 \mathrm{mM} \mathrm{NaCl}, 0.5$ mM TCEP using gel filtration on a Superdex S75 16/600 or Superdex S200 16/600 column (GE Healthcare).

Unlabeled EB1 for electrophoretic mobility shift assay (EMSA) or for the MT competition assay was expressed in Luria-Bertani (LB) medium.

\section{NMR experiments}

NMR spectra were acquired at $298 \mathrm{~K}$ on Bruker Avance III 600 and $800 \mathrm{MHz}$ spectrometers equipped with a cryogenic triple 
resonance probe and a Bruker Avance III $700 \mathrm{MHz}$ spectrometer equipped with a room temperature triple resonance probe.

NMR titrations were done at protein concentrations of $100 \mu \mathrm{M}$ in $20 \mathrm{mM} \mathrm{Na}_{2} \mathrm{HPO}_{4}, 150 \mathrm{mM} \mathrm{NaCl}, 1 \mathrm{mM} \mathrm{TCEP}$ at pH 6.5 and $10 \mathrm{mM}$ poly(U) 6-, 9- 15- or 25-mer RNA (Integrated DNA Technologies) or $2.5 \mathrm{mM}$ yeast tRNA (Merck) in the same buffer were added stepwise. At each titration point a ${ }^{1} \mathrm{H}-{ }^{15} \mathrm{~N}-\mathrm{HSOC}$ was recorded. Spectra were processed using NMRPipe (Delaglio et al. 1995) and visualized using SPARKY (Goddard and Kneller, SPARKY 3， v.3.115, https://www.cgl.ucsf.edu/home/sparky [University of California, 2015]). Dissociation constants from chemical shift perturbations were derived according to Fielding (2003). Backbone assignment for the EB1-Nlinker (residues 1-209) was performed using CCPNMR (Skinner et al. 2016) based HNCA, HNCACB, and HNCOCACB experiments (Sattler et al. 1999). $H N N$ and $H N(C) N$-correlated experiments were additionally required to assign backbone chemical shifts of aTm1 due to its intrinsically disordered state (Bracken et al. 1997; Panchal et al. 2001). Experiments were recorded using apodization weighted sampling (Simon and Kostler 2019). All backbone chemical shifts have been deposited at the BMRB (EB $1^{1-209}$ accession code: 50743 , aTm $1^{1-}$ 213 accession code: 50940$)$.

\section{Electrophoretic mobility shift assay (EMSA)}

Poly(U) 25-mer RNA synthetic probe (IDT) was labeled at the $5^{\prime}$ end with ATP, $\left[\gamma_{-}{ }^{32} \mathrm{P}\right]$ (Hartmann Analytic) using T4 polynucleotide kinase (Thermo Fisher) and subsequently purified using Illustra Microspin G25 columns (GE Healthcare). Recombinant EB1 (0.5, $1,5,10,20,40 \mu \mathrm{M}$ ) was mixed with $2.5 \mathrm{nM}$ probe in $20 \mathrm{mM}$ Tris$\mathrm{HCl}, 7.5 ; 150 \mathrm{mM} \mathrm{NaCl}, 2 \mathrm{mM} \mathrm{MgCl}$, $10 \%$ glycerol, $1 \mathrm{mM}$ DTT binding buffer in $20 \mu \mathrm{L}$ reactions and incubated on ice for $1 \mathrm{~h}$. The samples were subsequently separated on $6 \%$ native $0.5 \times$ TBE polyacrylamide gel for $1 \mathrm{~h}$ at $100 \mathrm{~V}$. The gel was then dried and exposed overnight to a storage phosphor screen (GE), which was finally visualized with a Typhoon Trio Imager (GE Healthcare).

\section{Cosedimentation assay}

The cosedimentation assay was adapted from the in vitro polymerization assay from Venkei et al. (2006) as follows: $60 \mu \mathrm{M}$ porcine brain tubulin (Cytoskeleton) was polymerized into microtubules in BRB80 buffer $(1 \times)(80 \mathrm{mM}$ PIPES, $1 \mathrm{mM} \mathrm{MgCl}$, $1 \mathrm{mM}$ EGTA, pH 6.8 with $\mathrm{KOH}$ ) containing $2 \mathrm{mM}$ GTP $\gamma \mathrm{S}$ (Sigma) and $20 \mu \mathrm{M}$ taxol (Sigma) at $37^{\circ} \mathrm{C}$ for $30 \mathrm{~min}$. Meanwhile, EB1-RNA complexes were formed with $40 \mu \mathrm{M}$ purified recombinant EB1 and increasing concentrations of poly(U) 25-mer RNA $(0 \mu \mathrm{M}$ to $320 \mu \mathrm{M})$ on ice. The complex was added to polymerized MTs and incubated for $15 \mathrm{~min}$ at room temperature. The samples were carefully layered onto $30 \%$ sucrose cushion in BRB80 $(1 \times)$ buffer with taxol and centrifuged at $80,000 \mathrm{~g}$ for 30 min using a Beckman SW55Ti rotor. The supernatant was saved and the pellet was washed with BRB80 $(1 \times)$ plus taxol twice, before resuspending it in $50 \mu \mathrm{L}$ BRB80 $(1 \times)$ with taxol. A total of $5 \mu \mathrm{L}$ of the sample was loaded onto $15 \%$ urea PAGE to observe the RNA, and $5 \mu \mathrm{L}$ was loaded onto SDS-PAGE to observe tubulin and EB1, in the supernatant and pellet fractions. RNA was stained with methylene blue, and the proteins were stained with InstantBlue from Expedeon.

\section{RNA-immunoprecipitation followed by sequencing (RIP-seq)}

Ovaries were collected from flies expressing EB1-GFP, lysed in lysis buffer ( $20 \mathrm{mM}$ Hepes [pH 7.5], $100 \mathrm{mM} \mathrm{KCl}, 1 \mathrm{mM} \mathrm{MgCl}$, with freshly added $80 \mathrm{U} / \mathrm{mL}$ RiboLock [Thermo Scientific], 0.05\% NP-40 and $1 \times$ Roche Protease Inhibitor Cocktail) and cleared at $13,200 \mathrm{rpm}$ at $4^{\circ} \mathrm{C}$ for $10 \mathrm{~min}$. The lysate was cross-linked with $U V$ at $0.3 \mathrm{~J}$, and subsequently was incubated with magnetic GFP trap beads from Chromotek for $1.5 \mathrm{~h}$ at $4^{\circ} \mathrm{C}$. The beads were then washed with high salt buffer (20 mM Hepes [pH 7.5], $1 \mathrm{M}$ $\mathrm{NaCl}, 1 \mathrm{mM}$ EDTA, 0.5\% NP-40 and freshly added $0.5 \mathrm{mM}$ DTT, $80 \mathrm{U} / \mathrm{mL}$ RiboLock and $1 \times$ Roche Protease Inhibitor Cocktail), followed by medium salt (20 mM Hepes [pH 7.5], 500 $\mathrm{mM} \mathrm{NaCl}, 1 \mathrm{mM}$ EDTA, 0.5\% NP-40 and freshly added $0.5 \mathrm{mM}$ DTT, $80 \mathrm{U} / \mathrm{mL}$ RiboLock and $1 \times$ Roche Protease Inhibitor Cocktail) and finally low salt buffer (20 mM Hepes [pH 7.5], 150 $\mathrm{mM} \mathrm{NaCl}, 1 \mathrm{mM}$ EDTA, 0.5\% NP-40 and freshly added $0.5 \mathrm{mM}$ DTT, $80 \mathrm{U} / \mathrm{mL}$ RiboLock and $1 \times$ Roche Protease Inhibitor Cocktail). The beads were resuspended in $100 \mu \mathrm{L}$ proteinase $\mathrm{K}$ buffer (20 mM Hepes [pH7.5], $150 \mathrm{mM} \mathrm{NaCl}$ and 1\% SDS) and treated with $0.2 \mathrm{mg} / \mathrm{mL}$ proteinase $\mathrm{K}$ (Invitrogen) for $30 \mathrm{~min}$ at $55^{\circ} \mathrm{C}$. Following the treatment, RNA was extracted with TRIzol LS, following manufacturer's instructions. The RNAs extracted from EB1-GFP and GFP samples were used to prepare cDNA libraries using a SENSE mRNA-seq Library Prep Kit V2 (Lexogen) and analyzed by single-end 50 sequencing on an Illumina HiSeq2000. The data were analyzed for differential gene expression between EB1-GFP and GFP samples using DESeq2 (Love et al. 2014). The raw data have been deposited in the ArrayExpress database at EMBL-EBI (www.ebi.ac.uk/ arrayexpress) under accession number E-MTAB-9078.

\section{Drosophila ovaries single molecule fluorescent in situ hybridization (smFISH) and image analysis}

Probes for the 12 candidate RNAs were labeled as in Gaspar et al. (2017b) and single molecule FISH performed as in Gáspár et al. (2017a). Two to three pairs of Drosophila ovaries from EB1-GFP expressing flies (Rogers et al. 2008; Sysoev et al. 2016) were dissected and fixed with $2 \mathrm{v} / \mathrm{v} \%$ PFA, $0.05 \mathrm{v} /$ v\% Triton X-100 in PBS ( $\mathrm{pH} 7.4$ ) for 20 min on orbital shaker. The fixative was removed and the ovaries were washed twice with PBT (PBS + 0.1 v/v\% Triton X-100, $\mathrm{pH} \mathrm{7.4)} \mathrm{for} 10 \mathrm{~min}$ each. Ovaries were then prehybridized in $100 \mu \mathrm{L}$ hybridization buffer $(300 \mathrm{mM} \mathrm{NaCl}, 30 \mathrm{mM}$ sodium citrate $\mathrm{pH} 7.0,15 \mathrm{v} / \mathrm{v} \%$ ethylene carbonate, $1 \mathrm{mM}$ EDTA, $50 \mu \mathrm{g} / \mathrm{mL}$ heparin, $100 \mu \mathrm{g} /$ $\mathrm{mL}$ salmon sperm DNA, $1 \mathrm{v} / \mathrm{v} \%$ Triton $\mathrm{X}-100)$ for $15 \mathrm{~min}$ at $42^{\circ} \mathrm{C}$. A total of $100 \mu \mathrm{L}$ of prewarmed probe mixture ( $25 \mathrm{nM}$ per individual oligonucleotide in hybridization buffer) was added to the prehybridization mixture, and the sample was incubated for $2 \mathrm{~h}$ at $42^{\circ} \mathrm{C}$. After hybridization, the following washes were performed to remove excess probes: A total of $1 \mathrm{~mL}$ prewarmed hybridization buffer, $1 \mathrm{~mL}$ prewarmed hybridization buffer:PBT 1:1 mixture, $1 \mathrm{~mL}$ prewarmed PBT for $10 \mathrm{~min}$ at $42^{\circ} \mathrm{C}$, and finally $1 \mathrm{~mL}$ PBT at room temperature. Ovaries were mounted in $80 \mathrm{v} / \mathrm{v}$ $\%$ 2,2-thiodiethanol in PBS and viewed using Leica TCS SP8 confocal microscope. The images were analyzed in ImageJ 
using particle detection and object based colocalization algorithm, as in Gáspár et al. (2017a).

\section{S2 cell transfection and smFISH}

EB1 was amplified from pET24d-His-TEV-EB1 plasmid using the primers 5'-CACCATGGCTGTAAACGTCTACTC-3' and 5'TTACTTGTAGAGCTCGTCCATGC-3' and inserted into pENTR/ D-TOPO (Invitrogen). Using Gateway LR Clonase II (Invitrogen), the insert was moved into the vector pAWG from the Drosophila Gateway Vector Collection (https://emb.carnegiescience.edu/ drosophila-gateway-vector-collection). S2 cells were transfected with pA-EB1-GFP using Effectene Transfection Reagent (Qiagen) following the manufacturer's protocol. $1 \times 10^{5}$ of the transfected cells were seeded onto concanavalin A coated coverslips and incubated at $25^{\circ} \mathrm{C}$ for $1 \mathrm{~h}$. The cells were then washed once with PBS and incubated in $2 \%$ paraformaldehyde for $30 \mathrm{~min}$ at room temperature followed by washing with PBS and incubation in wash buffer (25\% formamide and $2 \times$ Saline Sodium Citrate Buffer) for $5 \mathrm{~min}$. A total of $200 \mu \mathrm{L}$ hybridization buffer ( $25 \%$ formamide, $2 \times$ Saline Sodium Citrate Buffer, 0.02\% BSA, 2 mM vanadyl ribonucleoside complex) containing smFISH probes at a final concentration of $0.5 \mathrm{pg} /$ nucleotide $/ \mathrm{mL}$ was then added to the cells and they were incubated at $30^{\circ} \mathrm{C}$ overnight, in a humid chamber. Next, the cells were washed twice in wash buffer for $30 \mathrm{~min}$ each at $30^{\circ} \mathrm{C}$, followed by incubation in $2.5 \mu \mathrm{g} / \mathrm{mL}$ DAPI in wash buffer for $10 \mathrm{~min}$ at room temperature. The coverslips were finally mounted on glass slides in Immu-Mount media (Thermo Scientific) and viewed using a Leica TCS SP8 confocal microscope.

\section{SUPPLEMENTAL MATERIAL}

Supplemental material is available for this article.

\section{ACKNOWLEDGMENTS}

We thank the Genomics Core Facility at EMBL for performing the sequencing of the RIP samples. This work was supported by an EIPOD fellowship to L.D-P., cofunded by Marie Curie Actions Cofund and EMBL MSCA-COFUND-FP (664726). J.H. kindly acknowledges support via an Emmy-Noether Fellowship (HE 7291). L.D-P., V., and this study were supported by the Priority Program SPP1935 (EP 37/3-1, 3-2) grant of the Deutsche Forschungsgemeinschaft (DFG) to A.E. and J.H. We gratefully acknowledge the support of the EMBL.

Author contributions: V., L.D-P., K.H., A.E., and J.H. conceived the study and wrote the manuscript. M.S. purified FPR1. The rest of the experiments and data analysis were carried out by V., L.DP., and K.H.

Received February 3, 2021; accepted June 29, 2021.

\section{REFERENCES}

Akhmanova A, Steinmetz MO. 2008. Tracking the ends: a dynamic protein network controls the fate of microtubule tips. Nat Rev Mol Cell Biol 9: 309-322. doi:10.1038/nrm2369

Ankush Jagtap PK, Muller M, Masiewicz P, von Bulow S, Hollmann NM, Chen PC, Simon B, Thomae AW, Becker PB,
Hennig J. 2019. Structure, dynamics and roX2-IncRNA binding of tandem double-stranded RNA binding domains dsRBD1,2 of Drosophila helicase Maleless. Nucleic Acids Res 47: 4319-4333. doi:10.1093/nar/gkz125

Balcerak A, Trebinska-Stryjewska A, Konopinski R, Wakula M, Grzybowska EA. 2019. RNA-protein interactions: disorder, moonlighting and junk contribute to eukaryotic complexity. Open Biol 9: 190096. doi:10.1098/rsob.190096

Baltz AG, Munschauer M, Schwanhausser B, Vasile A, Murakawa $Y$, Schueler M, Youngs N, Penfold-Brown D, Drew K, Milek M, et al. 2012. The mRNA-bound proteome and its global occupancy profile on protein-coding transcripts. Mol Cell 46: 674-690. doi:10 .1016/j.molcel.2012.05.021

Beckmann BM, Horos R, Fischer B, Castello A, Eichelbaum K, Alleaume AM, Schwarzl T, Curk T, Foehr S, Huber W, et al. 2015. The RNA-binding proteomes from yeast to man harbour conserved enigmRBPs. Nat Commun 6: 10127. doi:10.1038/ ncomms 10127

Belhasan DC, Akaaboune M. 2020. The role of the dystrophin glycoprotein complex on the neuromuscular system. Neurosci Lett 722: 134833. doi:10.1016/j.neulet.2020.134833

Ben-Shem A, Garreau de Loubresse N, Melnikov S, Jenner L, Yusupova G, Yusupov M. 2011. The structure of the eukaryotic ribosome at $3.0 \AA$ resolution. Science 334: 1524-1529. doi:10 $.1126 /$ science. 1212642

Bracken C, Palmer AG III, Cavanagh J. 1997. (H)N(COCA)NH and HN (COCA)NH experiments for ${ }^{1} \mathrm{H}^{15} \mathrm{~N}$ backbone assignments in ${ }^{13} \mathrm{C} /{ }^{15} \mathrm{~N}$-labeled proteins. J Biomol NMR 9: 94-100. doi:10 .1023/A:1018679819693

Brown JB, Boley N, Eisman R, May GE, Stoiber MH, Duff MO, Booth BW, Wen J, Park S, Suzuki AM, et al. 2014. Diversity and dynamics of the Drosophila transcriptome. Nature 512: 393-399. doi:10.1038/nature12962

Castello A, Fischer B, Eichelbaum K, Horos R, Beckmann BM, Strein C, Davey NE, Humphreys DT, Preiss T, Steinmetz LM, et al. 2012. Insights into RNA biology from an atlas of mammalian mRNAbinding proteins. Cell 149: 1393-1406. doi:10.1016/j.cell.2012 .04 .031

Castello A, Hentze MW, Preiss T. 2015. Metabolic enzymes enjoying new partnerships as RNA-binding proteins. Trends Endocrinol Metab 26: 746-757. doi:10.1016/j.tem.2015.09.012

Castello A, Fischer B, Frese CK, Horos R, Alleaume AM, Foehr S, Curk T, Krijgsveld J, Hentze MW. 2016a. Comprehensive identification of RNA-binding domains in human cells. Mol Cell 63: 696710. doi:10.1016/j.molcel.2016.06.029

Castello A, Horos R, Strein C, Fischer B, Eichelbaum K, Steinmetz LM, Krijgsveld J, Hentze MW. 2016b. Comprehensive identification of RNA-binding proteins by RNA interactome capture. Methods $\mathrm{Mol}$ Biol 1358: 131-139. doi:10.1007/978-1-4939-3067-8_8

Cech TR, Steitz JA. 2014. The noncoding RNA revolution-trashing old rules to forge new ones. Cell 157: 77-94. doi:10.1016/j.cell.2014 .03 .008

Chong PA, Vernon RM, Forman-Kay JD. 2018. RGG/RG motif regions in RNA binding and phase separation. J Mol Biol 430: 4650-4665. doi:10.1016/j.jmb.2018.06.014

Choudhury NR, Michlewski G. 2019. Quantitative identification of proteins that influence miRNA biogenesis by RNA pull-downSILAC mass spectrometry (RP-SMS). Methods 152: 12-17. doi:10.1016/j.ymeth.2018.06.006

Choudhury NR, Heikel G, Trubitsyna M, Kubik P, Nowak JS, Webb S, Granneman S, Spanos C, Rappsilber J, Castello A, et al. 2017. RNA-binding activity of TRIM25 is mediated by its PRY/SPRY domain and is required for ubiquitination. BMC Biol 15: 105. doi:10.1186/s12915-017-0444-9 
Corley M, Burns MC, Yeo GW. 2020. How RNA-binding proteins interact with RNA: molecules and mechanisms. Mol Cell 78: 9-29. doi:10.1016/j.molcel.2020.03.011

Delaglio F, Grzesiek S, Vuister GW, Zhu G, Pfeifer J, Bax A. 1995 NMRPipe: a multidimensional spectral processing system based on UNIX pipes. J Biomol NMR 6: 277-293. doi:10.1007/ BF00197809

de Marco A, Deuerling E, Mogk A, Tomoyasu T, Bukau B. 2007. Chaperone-based procedure to increase yields of soluble recombinant proteins produced in E. coli. BMC Biotechnol 7: 32. doi:10 $.1186 / 1472-6750-7-32$

Dimitrova L, Valkov E, Aibara S, Flemming D, McLaughlin SH, Hurt E, Stewart M. 2015. Structural characterization of the Chaetomium thermophilum TREX-2 complex and its interaction with the mRNA nuclear export factor Mex67:Mtr2. Structure 23: 12461257. doi:10.1016/j.str.2015.05.002

Dimitrova-Paternoga L, Jagtap PKA, Chen PC, Hennig J. 2020. Integrative structural biology of protein-RNA complexes. Structure 28: 6-28. doi:10.1016/j.str.2019.11.017

Dimitrova-Paternoga L, Jagtap PKA, Cyrklaff A, Vaishali, Lapouge K, Sehr P, Perez K, Heber S, Löw C, Hennig J, et al. 2021. Molecular basis of mRNA transport by a kinesin-1-atypical tropomyosin complex. Genes Dev 35: 976-991. doi:10.1101/gad.348443.121

Dreyfuss G, Choi YD, Adam SA. 1984. Characterization of heterogeneous nuclear RNA-protein complexes in vivo with monoclonal antibodies. Mol Cell Biol 4: 1104-1114. doi:10.1128/MCB.4.6 .1104

Dzhindzhev NS, Rogers SL, Vale RD, Ohkura H. 2005. Distinct mechanisms govern the localisation of Drosophila CLIP-190 to unattached kinetochores and microtubule plus-ends. J Cell Sci 118: 3781-3790. doi:10.1242/jcs.02504

Fernandez-Chamorro J, Francisco-Velilla R, Ramajo J, MartinezSalas E. 2019. Rab1b and ARF5 are novel RNA-binding proteins involved in FMDV IRES-driven RNA localization. Life Sci Alliance 2: e201800131. doi:10.26508/Isa.201800131

Fielding L. 2003. NMR methods for the determination of protein-ligand dissociation constants. Curr Top Med Chem 3: 39-53. doi:10.2174/1568026033392705

Gáspár I, Sysoev V, Komissarov A, Ephrussi A. 2017a. An RNA-binding atypical tropomyosin recruits kinesin-1 dynamically to oskar mRNPs. EMBO J 36: 319-333. doi:10.15252/embj.201696038

Gaspar I, Wippich F, Ephrussi A. 2017b. Enzymatic production of single-molecule FISH and RNA capture probes. RNA 23: 1582-1591. doi:10.1261/rna.061184.117

Gelbart WM, Emmert DB. 2013. FlyBase High Throughput Expression Pattern Data. https://flybase.org/reports/FBrf0221009.html

Gerstberger S, Hafner M, Tuschl T. 2014. A census of human RNAbinding proteins. Nat Rev Genet 15: 829-845. doi:10.1038/ nrg3813

Gireesh KK, Shine A, Lakshmi RB, Vijayan V, Manna TK. 2018. GTPbinding facilitates EB1 recruitment onto microtubules by relieving its auto-inhibition. Sci Rep 8: 9792. doi:10.1038/s41598-01828056-y

Haubrich K, Augsten S, Simon B, Masiewicz P, Perez K, Lethier M, Rittinger K, Gabel F, Cusack S, Hennig J. 2020. RNA binding regulates TRIM25-mediated RIG-I ubiquitylation. bioRxiv doi:10 .1101/2020.05.04.070177

Hausch F, Kozany C, Theodoropoulou M, Fabian AK. 2013. FKBPs and the Akt/mTOR pathway. Cell Cycle 12: 2366-2370. doi:10.4161/ cc. 25508

Hennig J, Militti C, Popowicz GM, Wang I, Sonntag M, Geerlof A, Gabel F, Gebauer F, Sattler M. 2014. Structural basis for the assembly of the Sxl-Unr translation regulatory complex. Nature 515: 287-290. doi:10.1038/nature13693
Hentze MW, Castello A, Schwarzl T, Preiss T. 2018. A brave new world of RNA-binding proteins. Nat Rev Mol Cell Biol 19: 327-341. doi:10.1038/nrm.2017.130

Hollmann NM, Jagtap PKA, Masiewicz P, Guitart T, Simon B, Provaznik J, Stein F, Haberkant P, Sweetapple LJ, Villacorta L, et al. 2020. Pseudo-RNA-binding domains mediate RNA structure specificity in upstream of N-Ras. Cell Rep 32: 107930. doi:10 .1016/j.celrep.2020.107930

Horos R, Buscher M, Sachse C, Hentze MW. 2019. Vault RNA emerges as a regulator of selective autophagy. Autophagy 15: 1463-1464. doi:10.1080/15548627.2019.1609861

Huppertz I, Perez-Perri JI, Mantas P, Sekaran T, Schwarzl T, DimitrovaPaternoga L, Hennig J, Neveu PA, Hentze MW. 2020. RNA regulates glycolysis and embryonic stem cell differentiation via enolase 1. bioRxiv doi: $10.1101 / 2020.10 .14 .337444$

Kelley LA, Sternberg MJ. 2009. Protein structure prediction on the Web: a case study using the Phyre server. Nat Protoc 4: 363371. doi:10.1038/nprot.2009.2

Klinge S, Voigts-Hoffmann F, Leibundgut M, Arpagaus S, Ban N. 2011. Crystal structure of the eukaryotic 605 ribosomal subunit in complex with initiation factor 6. Science 334: 941-948. doi:10 $.1126 /$ science.1211204

Klinge S, Voigts-Hoffmann F, Leibundgut M, Ban N. 2012. Atomic structures of the eukaryotic ribosome. Trends Biochem Sci 37: 189-198. doi:10.1016/j.tibs.2012.02.007

Koliopoulos MG, Lethier M, van der Veen AG, Haubrich K, Hennig J, Kowalinski E, Stevens RV, Martin SR, Reis e Sousa C, Cusack S, et al. 2018. Molecular mechanism of influenza A NS1-mediated TRIM25 recognition and inhibition. Nat Commun 9: 1820. doi:10 .1038/s41467-018-04214-8

Kolos JM, Voll AM, Bauder M, Hausch F. 2018. FKBP ligands-where we are and where to go? Front Pharmacol 9: 1425. doi:10.3389/ fphar.2018.01425

Kwon SC, Yi H, Eichelbaum K, Fohr S, Fischer B, You KT, Castello A, Krijgsveld J, Hentze MW, Kim VN. 2013. The RNA-binding protein repertoire of embryonic stem cells. Nat Struct Mol Biol 20: 11221130. doi:10.1038/nsmb.2638

Lai C, Liu L, Liu Q, Cheng S, Wang K, Zhao L, Xia M, Wang C, Gu H, Duan $Y$, et al. 2019. Long noncoding RNA AVAN promotes antiviral innate immunity by interacting with TRIM 25 and enhancing the transcription of FOXO3a. bioRxiv doi:10.1101/623132

Lee S, Kim SM, Lee RT. 2013. Thioredoxin and thioredoxin target proteins: from molecular mechanisms to functional significance. Antioxid Redox Signal 18: 1165-1207. doi:10.1089/ars.2011 .4322

Lee NR, Choi JY, Yoon IH, Lee JK, Inn KS. 2018. Positive regulatory role of c-Src-mediated TRIM25 tyrosine phosphorylation on RIG-I ubiquitination and RIG-I-mediated antiviral signaling pathway. Cell Immunol 332: 94-100. doi:10.1016/j.cellimm.2018.08.004

Lin H, Jiang M, Liu L, Yang Z, Ma Z, Liu S, Ma Y, Zhang L, Cao X. 2019. The long noncoding RNA Lnczc3h7a promotes a TRIM25-mediated RIG-I antiviral innate immune response. Nat Immunol 20: 812823. doi:10.1038/s41590-019-0379-0

Liu L, Li T, Song G, He Q, Yin Y, Lu JY, Bi X, Wang K, Luo S, Chen YS, et al. 2019. Insight into novel RNA-binding activities via large-scale analysis of IncRNA-bound proteome and IDH1-bound transcriptome. Nucleic Acids Res 47: 2244-2262. doi:10.1093/nar/gkz032

Loedige I, Jakob L, Treiber T, Ray D, Stotz M, Treiber N, Hennig J, Cook KB, Morris Q, Hughes TR, et al. 2015. The crystal structure of the NHL domain in complex with RNA reveals the molecular basis of Drosophila brain-tumor-mediated gene regulation. Cell Rep 13: 1206-1220. doi:10.1016/j.celrep.2015.09.068

Loedige I, Stotz M, Qamar S, Kramer K, Hennig J, Schubert T, Loffler P, Langst G, Merkl R, Urlaub H, et al. 2014. The NHL domain of BRAT is an RNA-binding domain that directly contacts the 
hunchback mRNA for regulation. Genes Dev 28: 749-764. doi:10 $.1101 /$ gad.236513.113

Love MI, Huber W, Anders S. 2014. Moderated estimation of fold change and dispersion for RNA-seq data with DESeq2. Genome Biol 15: 550. doi:10.1186/s13059-014-0550-8

Lunde BM, Moore C, Varani G. 2007. RNA-binding proteins: modular design for efficient function. Nat Rev Mol Cell Biol 8: 479-490. doi:10.1038/nrm2178

Manokaran G, Finol E, Wang C, Gunaratne J, Bahl J, Ong EZ, Tan HC, Sessions OM, Ward AM, Gubler DJ, et al. 2015. Dengue subgenomic RNA binds TRIM25 to inhibit interferon expression for epidemiological fitness. Science 350: 217-221. doi:10.1126/science .aab3369

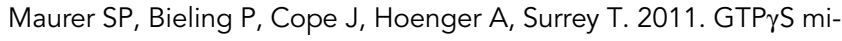
crotubules mimic the growing microtubule end structure recognized by end-binding proteins (EBs). Proc Natl Acad Sci 108: 3988. doi:10.1073/pnas.1014758108

Meyerson H, Awadallah A, Blidaru G, Osei E, Schlegelmilch J, Egler R, Abu-Arja R, Ding H. 2017. Juvenile myelomonocytic leukemia with prominent CD141+ myeloid dendritic cell differentiation. Hum Pathol 68: 147-153. doi:10.1016/j.humpath.2017.03.025

Mitchell SF, Jain S, She M, Parker R. 2013. Global analysis of yeast mRNPs. Nat Struct Mol Biol 20: 127-133. doi:10.1038/nsmb.2468

Nehlig A, Molina A, Rodrigues-Ferreira S, Honoré S, Nahmias C. 2017. Regulation of end-binding protein EB1 in the control of microtubule dynamics. Cell Mol Life Sci 74: 2381-2393. doi:10.1007/ s00018-017-2476-2

Orimo A, Inoue S, Minowa O, Tominaga N, Tomioka $Y$, Sato $M$, Kuno J, Hiroi H, Shimizu Y, Suzuki M, et al. 1999. Underdeveloped uterus and reduced estrogen responsiveness in mice with disruption of the estrogen-responsive finger protein gene, which is a direct target of estrogen receptor $\alpha$. Proc Natl Acad Sci 96: 1202712032. doi:10.1073/pnas.96.21.12027

Panchal SC, Bhavesh NS, Hosur RV. 2001. Improved 3D triple resonance experiments, $\mathrm{HNN}$ and $\mathrm{HN}(\mathrm{C}) \mathrm{N}$, for $\mathrm{HN}$ and ${ }^{15} \mathrm{~N}$ sequential correlations in $\left({ }^{13} \mathrm{C},{ }^{15} \mathrm{~N}\right)$ labeled proteins: application to unfolded proteins. J Biomol NMR 20: 135-147. doi:10.1023/A :1011239023422

Perez-Perri JI, Rogell B, Schwarzl T, Stein F, Zhou Y, Rettel M, Brosig A, Hentze MW. 2018. Discovery of RNA-binding proteins and characterization of their dynamic responses by enhanced RNA interactome capture. Nat Commun 9: 4408. doi:10.1038/s41467-01806557-8

Phan AT, Kuryavyi V, Darnell JC, Serganov A, Majumdar A, llin S, Raslin T, Polonskaia A, Chen C, Clain D, et al. 2011. Structure-function studies of FMRP RGG peptide recognition of an RNA duplexquadruplex junction. Nat Struct Mol Biol 18: 796-804. doi:10 .1038/nsmb.2064

Pinol-Roma S, Choi YD, Matunis MJ, Dreyfuss G. 1988. Immunopurification of heterogeneous nuclear ribonucleoprotein particles reveals an assortment of RNA-binding proteins. Genes Dev 2: 215-227. doi:10.1101/gad.2.2.215

Preitner N, Quan J, Nowakowski DW, Hancock ML, Shi J, Tcherkezian J, Young-Pearse TL, Flanagan JG. 2014. APC is an RNA-binding protein, and its interactome provides a link to neural development and microtubule assembly. Cell 158: 368-382. doi:10.1016/j.cell.2014.05.042

Rogers SL, Rogers GC, Sharp DJ, Vale RD. 2002. Drosophila EB1 is important for proper assembly, dynamics, and positioning of the mi- totic spindle. J Cell Biol 158: 873-884. doi:10.1083/jcb .200202032

Rogers GC, Rusan NM, Peifer M, Rogers SL. 2008. A multicomponent assembly pathway contributes to the formation of acentrosomal microtubule arrays in interphase Drosophila cells. Mol Biol Cell 19: 3163-3178. doi:10.1091/mbc.e07-10-1069

Ryder SP. 2016. Protein-mRNA interactome capture: cartography of the mRNP landscape. F1000Res 5: 2627. doi:10.12688/f1000re search.9404.1

Sattler M, Schleucher J, Griesinger C. 1999. Heteronuclear multidimensional NMR experiments for the structure determination of proteins in solution employing pulsed field gradients. Prog Nucl Magn Reson Spectrosc 34: 93-158. doi:10.1016/S0079-6565(98) 00025-9

Simon B, Kostler H. 2019. Improving the sensitivity of FT-NMR spectroscopy by apodization weighted sampling. J Biomol NMR 73: 155-165. doi:10.1007/s10858-019-00243-7

Skinner SP, Fogh RH, Boucher W, Ragan TJ, Mureddu LG, Vuister GW. 2016. CcpNmr AnalysisAssign: a flexible platform for integrated NMR analysis. J Biomol NMR 66: 111-124. doi:10.1007/s10858016-0060-y

Song B, Gold B, O'Huigin C, Javanbakht H, Li X, Stremlau M, Winkler C, Dean M, Sodroski J. 2005. The B30.2(SPRY) domain of the retroviral restriction factor TRIM5 $\alpha$ exhibits lineage-specific length and sequence variation in primates. J Virol 79: 6111-6121. doi:10.1128/JVI.79.10.6111-6121.2005

Sysoev VO, Fischer B, Frese CK, Gupta I, Krijgsveld J, Hentze MW, Castello A, Ephrussi A. 2016. Global changes of the RNA-bound proteome during the maternal-to-zygotic transition in Drosophila. Nat Commun 7: 12128. doi:10.1038/ncomms12128

Vaughan KT. 2005. TIP maker and TIP marker; EB1 as a master controller of microtubule plus ends. J Cell Biol 171: 197-200. doi:10 $.1083 /$ jcb. 200509150

Veeranan-Karmegam R, Boggupalli DP, Liu G, Gonsalvez GB. 2016. A new isoform of Drosophila non-muscle Tropomyosin 1 interacts with Kinesin-1 and functions in oskar mRNA localization. J Cell Sci 129: 4252-4264.

Venkei Z, Gáspár I, Tóth G, Szabad J. 2006. $\alpha 4$-Tubulin is involved in rapid formation of long microtubules to push apart the daughter centrosomes during early Drosophila embryogenesis. J Cell Sci 119: 3238-3248. doi:10.1242/jcs.03039

Weidmann CA, Qiu C, Arvola RM, Lou TF, Killingsworth J, Campbell ZT, Tanaka Hall TM, Goldstrohm AC. 2016. Drosophila Nanos acts as a molecular clamp that modulates the RNA-binding and repression activities of Pumilio. Elife 5: e17096. doi:10.7554/ elife. 17096

Wessels $\mathrm{H}-\mathrm{H}$, Imami K, Baltz AG, Kolinski M, Beldovskaya A Selbach M, Small S, Ohler U, Landthaler M. 2016. The mRNAbound proteome of the early fly embryo. Genome Res 26: 1000-1009. doi:10.1101/gr.200386.115

Williams FP, Haubrich K, Perez-Borrajero C, Hennig J. 2019. Emerging RNA-binding roles in the TRIM family of ubiquitin ligases. Biol Chem 400: 1443-1464. doi:10.1515/hsz-2019-0158

Zhang P, Elabd S, Hammer S, Solozobova V, Yan H, Bartel F, Inoue S, Henrich T, Wittbrodt J, Loosli F, et al. 2015a. TRIM25 has a dual function in the p53/Mdm2 circuit. Oncogene 34: 5729-5738. doi:10.1038/onc.2015.21

Zhang R, Alushin GM, Brown A, Nogales E. 2015b. Mechanistic origin of microtubule dynamic instability and its modulation by EB proteins. Cell 162: 849-859. doi:10.1016/j.cell.2015.07.012 